ISSN: 1838-3815 (online) Journal Homepage: https://ojs.deakin.edu.au/index.php/itlge/

\title{
Future-proofing accounting professionals: Ensuring graduate employability and future readiness
}

\author{
Marcus Bowles ${ }^{1}$, Samrat Ghosh ${ }^{1}$, Lisa Thomas ${ }^{2}$ \\ Corresponding author: Marcus Bowles (marc.bowles@utas.edu.au) \\ ${ }^{1}$ University of Tasmania, \\ ${ }^{2}$ Chartered Accountants Australia \& New Zealand
}

\begin{abstract}
Key international and Australasian bodies have reported research suggesting the accounting profession is one of the most vulnerable to disruption through automation and changed business models. But research discussed in this paper confirms that while component parts of an accounting 'job' will be replaced by technology, the capabilities required to perform remaining accounting and finance activities would not only endure, they would spread across many non-accounting roles. c This report presents the findings from the final stage of a validation process that was conducted by Chartered Accountants Australia and New Zealand (CA ANZ) across Australia and New Zealand. The report confirms 24 capabilities, including six considered essential requirements for every professional seeking to work in accounting, finance, and related work roles. The findings provide evidence that these capabilities, in contrast to recent reports suggesting employment opportunities for accounting graduates are in decline, can create opportunities for sustainable careers. The validation project and survey results provide unexpected insight into the capabilities of different age groups and professionals at different career stages that are considered important. The research outlined in this paper will not only inform continuing professional education for members but also help refine the design of post-graduate curriculum and continuing professional development.
\end{abstract}

Keywords: capabilities, professional capability standards, employability, graduate attributes, soft skills

\section{Introduction}

Chartered Accountants Australia and New Zealand (CA ANZ) has been confronting the problem faced by large professional bodies seeking to meet the challenges of automation and workforce transformation. How do they best ensure graduates choosing a professional career that the skills from accounting education would not only secure a job but also create a sustainable career pathway (Hancock et al., 2010)?

It is not a new idea to suggest professional bodies play a vital role in helping employers, students, and educational providers identify the capabilities required to succeed in the accounting profession (Big Eight, 1989; Siegel \& Sorensen, 1994). However, the future of the accounting profession has been subject to so much hyperbole and conflicting insights derived from data that CA ANZ (2017b) knew its future strategy would need to address a fundamental question (2nd Road, 2017):

How can we create relevance and value for our members and the community so that we can build a sustainable future for our profession? 
The most prominent contention seems to suggest that, while technology disruption is driving employment demand in the profession in some Western countries over the short term, automation will most seriously challenge employment growth in accounting and finance more than almost any other profession (Association of Chartered Certified Accountants [ACCA], 2016, pp. 11-12). Reinforcing this underlying anxiety, the World Economic Forum (WEF) predicted in 2018 that the effect of automation and robotic technologies would see professional accountants and auditors and the associated clerical roles in accounting, bookkeeping, and payroll effectively lose over $40 \%$ of the current employment numbers within five years, effectively becoming a redundant occupation across the globe by 2028 (WEF, 2018, p. 9). Moreover, research confirms that this decline would be seen across all major industry sectors (WEF, 2018, pp. 43-65) and make the accounting occupation most at risk for job loss caused by automation in regional Australia and New Zealand (Regional Australia Institute [RAI], 2018, p. 9; New Zealand Institute of Economic Research [NZIER], 2015, pp. 24, 26).

By way of contrast to this pessimistic backdrop, the demand for accountants seems to be growing. Experienced accountants remained in high demand in 2018 and 2019 in Australia and New Zealand. Whereas the para-professional or associate accounting roles, such as accounting clerks, remained in general decline, the average net profit of accounting firms continued to grow, albeit slower compared to the overall economy (The Benchmarking Group, 2019).

Preparing students for the changes likely to affect accountants is not something unexpected. There has been over a decade of criticism of universities failing to teach accounting graduates generic skills or prepare them for the emerging world of work in Australasia or other countries (Albrecht \& Sack, 2000; Smith, Maguire, \& Han, 2018). In 2016, the Australian Business Deans Council (ABDC, 2016) adopted the Australian Learning and Teaching Council's recommended threshold learning outcomes for accounting degrees (Hancock et al., 2010). These learning standards prescribe five interrelated graduate attributes for undergraduate bachelor's and master's degree accounting students. The learning standards include judgement, knowledge and critical analysis, problem-solving skills, communication, teamwork, and self-management (ABDC, 2016).

For over a decade, confusion has continued to reign over vital questions regarding how these categories of generic skills or graduate outcomes were to be implemented, for instance:

- Should the graduate attributes be embedded in the existing curriculum or assessed in isolation (McGuigan \& Kern, 2010)?

- Are the attributes separate or related skills? Answers to this varied, and a myriad of different ways emerged to bundle or co-assess different attributes (e.g., could communication be assessed with teamwork or with collaborative problem solving?) (Hancock et al., 2009).

- Can the universities continue to adapt and ensure graduates are equipped to complete everchanging work roles (Kavanagh \& Drennan, 2008; Albrecht \& Sack, 2000)?

- How can students and employers be assured that the non-technical skills were being given as much emphasis as technical skills and assessed relevant to the needs of various future employment contexts (Tempone, et al., 2011; Hancock, et al., 2010; Hancock, et al. 2016; Deloitte, 2017)?

- How could institutions assure employers that all the attributes were assessed to the same standard of employability (Jackling \& De Lange, 2009; Wells, Gerbic, Kranenburg, \& Bygrave, 2009; Towers-Clark, 2016)?

As both the professional body and partner or assurer that professional accounting degrees meet national and global standards CA ANZ, since its formation in late 2014 when the Institute of Chartered Accountants Australia and the New Zealand Institute of Chartered Accountants merged, has viewed supporting reforms to curriculum and professional skills development as one of its top priorities (CA ANZ, 2017b). More effort was required to ensure new graduates and chartered accountants were better equipped to undertake generic technical and professional tasks and had the mindset and emotional resilience necessary to succeed in the future workplace. 


\section{Disruption: Opportunity or threat?}

Prior to undertaking the capability research, CA ANZ commissioned a white paper into the Future Accountant (Bowles, 2018). The aim was to uncover how the accounting activities and tasks would be organised and how the role of an accountant would evolve over the coming decade. A secondary aim was to test and report the likely exposure of accounting activities to automation.

Research has uncovered that technology is not only changing the accountant's work activities and role in the economy, but is also altering how clients interact with accountants. In the face of a booming financial technology (FinTech) industry in Australia and New Zealand, the provision of accounting services, such as auditing of accounting records, preparing financial statements, preparing tax returns, and bookkeeping, have all been subject to radical innovation (The Benchmarking Group, 2019). For instance, online and cloud accounting platforms (e.g., MYOB and Xero) are capturing and shaping the relationship between the accountant and clients. The highscalability, personalisation, and global reach of these platforms continue to reshape accountants in every industry and region of Australia and New Zealand. Emerging developments in platforms and digital currency were also noted as having profound regional and global implications. Digital platforms and solutions, such as blockchain and cryptocurrency, hold enormous promise for new practices while being a threat to established accounting systems. They not only aggregate demand and provide a focal point for automation and opportunities to reduce labour intensive tasks but also improve efficiency and reduce the cost to clients, thus challenging the very nature of how accounting is undertaken (Deloitte, 2016). As accounting platforms continue to evolve, as with Uber, Airbnb, and similar models, disintermediation of the professional-client relationship will occur. This will give rise to alternative accounting services that will predominantly be delivered through digital and mobile channels directly to the client (Bowles, 2018, p. 15).

Despite this seemingly negative insight, the Future Accountant research confirmed significant opportunities for the accounting profession (Bowles, 2018). Disruption will also create new jobs. Across all industries, the end-customer, client, or business relationships are increasingly being conducted online. As disruption and new business models affect businesses, accountants will undertake essential activities, such as strategy formation, feasibility studies, business cases, compliance audits, financial risk analysis, and ongoing evaluation of transformation programs (Bowles, 2018; Deloitte, 2016). Many of these critical accounting activities and related capability requirements will, nonetheless, diffuse across new or emerging roles outside traditional accounting jobs and pathways, for instance, in work with emergent titles, such as sustainability analyst, systems accountant, agile manager, system transformation auditor, project finances coordinator, confidence assurance, and financial data analyst/scientist. We can already see capabilities of accountants and auditors matching the need for corporations desperately looking for skilled staff to fill recruitment needs in business intelligence, cybersecurity, crypto/digital currency, and blockchain roles (TingeyHolyoak \& Burritt, 2012).

Analysis of the reshaped future accounting role raised the question as to how a professional body such as CA ANZ could best equip and support members transitioning to a new service environment, and for members to support clients who will be early adopters and initiators of change? Just as the accounting industry must enhance its ability to adapt and evolve, its greatest opportunity will also come with roles associated with assisting clients and employers to transform and become more agile.

\section{Earlier research}

The formation of the Chartered Accountants Australia and New Zealand Capability Model (CACM) was not a greenfield exercise. Extensive research and data were drawn from four existing sources.

The first source of data was global frameworks. As part of the Global Accounting Alliance (GAA), CA ANZ has an obligation to align with the agreed curriculum and competency-related principles 
established for global accounting professionals. The global framework and the research and competency frameworks developed by member institutions provided a rich foundation for defining the skills, knowledge, and behavioural requirements. In particular, the work by the Canadian, Scottish, Irish, English, Welsh, and South African members of the GAA provided invaluable comparative taxonomies and competency dictionaries. Several guidance documents were also identified that set the rules and scope for any capability model, including the following:

- Accounting Professional Ethics \& Standards Board, APES 110 (APESB, 2018);

- Requirements set by the International Federation of Accountants (IFAC) and International Accounting Education Standards Board and distilled into the GAA (2019a, 2019b) competency framework and principles;

- The Accounting Learning Standards developed through the Australian Government Office for Learning and Teaching (formerly Australian Learning and Teaching Council) covering bachelor, entry and advanced coursework master degrees in accounting;

- GAA Accountant of the Future project (Oliver, 2018); and

- The CPA Canada chartered professional accountant competencies (CPAC, 2019).

Second, CA ANZ had just finalised a major research project to delimit the success profiles and behavioural competencies required by a professional accountant at each of three stages in their career: early career (new graduate), leader, and executive (CA ANZ, 2017a).

The global and Australian work on defining professional capabilities required in the future workplace provided a third, very rich field of insight (DeakinCo, 2017; DET, 2015; Gekara et al., 2019; Queensland Tertiary Admissions Centre [QTAC], 2019). This research complemented and, through semantic and comparative analysis (Bowles, 2016), reinforced global research that also sought to isolate the core skills or capabilities that would enhance employability in the 21st century (Frey, Osborne, \& Holmes, 2016; WEF, 2018; Organisation for Economic Co-operation and Development $[O E C D], 2015)$. Research also offered insight into where accounting employment and vulnerability of jobs to automation were unclear if analysis simply used existing occupational and workforce classifications, such as the Australian and New Zealand Standard Classification of Occupations (Australian Bureau of Statistics [ABS], 2013) or the U.S. Department of Labor's O*Net analysis (National Center for O*NET Development, 2019). By unbundling accounting jobs from the activity and task level, a far more reliable insight was gained. It showed where component parts of a 'job' would be replaced by technology, but the capabilities required to perform remaining accounting and finance activities would endure. In this sense, the capability model became a more reliable way to predict future employment than looking at jobs that were a backward examination of industrial age terminologies and boundaries.

The fourth and final source of information was the parallel project to redevelop the Chartered Accountants Program (CA Program). The redevelopment of the graduate diploma course involved broad and extensive consultation and co-design with CA ANZ members, academics, industry, and relevant global bodies. The new CA Program is being designed to maximise existing core strengths while developing new, highly effective areas that build the essential professional technical and nontechnical capabilities required by graduating chartered accountants seeking future ready, employable skills (CA ANZ, 2019c).

\section{The CA ANZ professional capability standards}

The CACM is a sensemaking model (see Figure 1 below). It is a strategic, overarching approach to promote more accurate forecasting and planning for the emerging needs of the CA ANZ members and the accounting workforce.

The CACM is intended to augment and support the better integration of solutions that CA ANZ has already invested in researching, designing, and testing with its members and other stakeholders. The CACM is structured around four domains: business (business context), leadership (people and 
future), personal (mindset and intellect), and technical (professional expertise). These domains emerged from a comparative analysis of existing research (CA ANZ, 2017b; ACCA, 2016; GAA Educational Directors, 2018; Bowles, 2019). The review of the global research confirmed the requirement of the following four domains that best represent the aspects of developing a future accountant:

- Personal - Who I am

- Business - How I operate

- Leadership - What I grow

- Technical - What I bring

The capabilities in the resulting CA ANZ model underpin the capacity of an organisation, industry, community, or professional workforce for action (Scott, Coates, \& Anderson, 2008). They delineate the ability or potential for the workforce and individuals to be flexible, innovative, adaptive, and responsive with agility and to maintain resilience in the face of challenges (Bowles \& Schoenheimer, 2009, pp. 27-28; McCann \& Selsky, 2012; Hamel, 2003).

Capabilities exist to emphasise and encompass more than occupational or vocational skill, knowledge or competencies. A capability framework is constructed to support strategic, systemlevel outcomes. It deliberately extends competency models (behavioural, technical, or vocational) to develop and assess dimensions, such as emotions and cognitive factors that enhance the deeper human capital value residing in the organisational culture and collaborative purpose (Teece, 2007; Bersin, Stempel, \& van der Vyver, 2014).

Professional capability frameworks grow current job competence and develop a person's future potential. This means they are built to provide a higher-level insight into the skills, knowledge, personal attributes, and mindsets that underpin the professional capacity required in the emerging workforce, not just for performance in a job.

Capability is compatible, but not interchangeable, with definitions of behavioural competence or a vocational competency, as instituted for accounting occupations under the Australian and New Zealand national training systems. However, many jurisdictions within the GAA, including CA ANZ, have previously promoted the idea that the capability was a sub-set or component of competence. This is misleading. Many competencies or related descriptors can co-exist under a capability framework. But capabilities do not need to be as granular in detail nor have assessment tied to behavioural attributes or vocational outcomes. This is wholly the domain of the competencies already used in the CA ANZ success profiles and competency frameworks developed by many GAA members. 


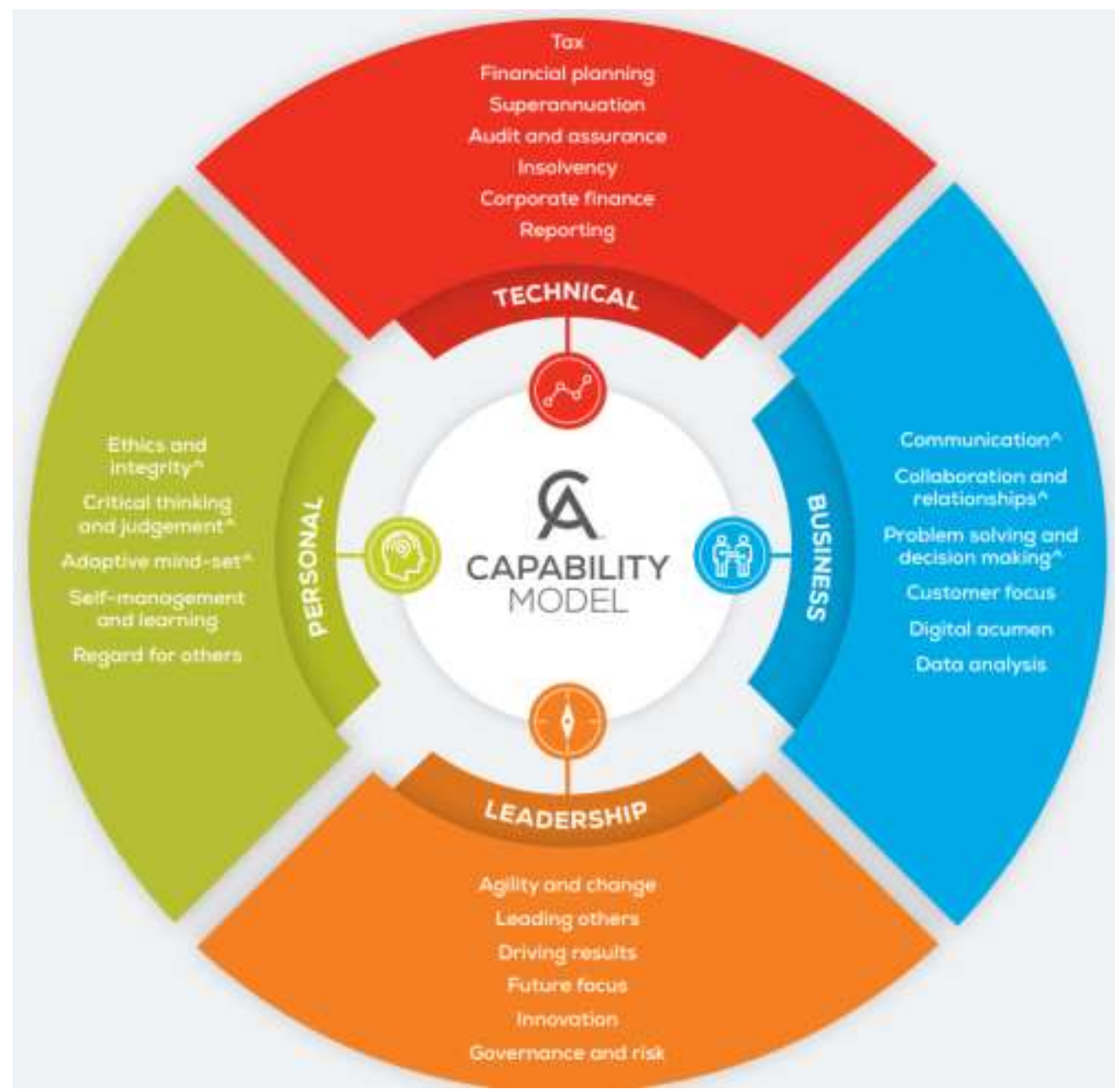

$\wedge$ These are the six non-technical capabilities considered essential for future employability of a professional accountant irrespective of their level of work, career stage, location or job role. The other non-technical capabilities, while critical, will vary in importance according to the job role.

\section{Figure 1: Chartered Accountants ANZ Capability Model}

\section{Human capabilities, soft skills, graduate attributes, and employability}

Just as the relationship between capabilities and competencies may be blurred, so can the relationship with frameworks seeking to define employability skills, soft skills, enterprise skills, or human capabilities relating to work in the fourth industrial age (Moore \& Morton, 2017; Crisp \& Oliver, 2019). As the concepts of a 'job', occupation, and how tasks are organised into work are changing, professional bodies, educators, and governments need to better identify the skills that will increase employability (Benbow \& Hora, 2018; AlphaBeta, 2019).

The preliminary research by CA ANZ confirmed that, while several tasks and activities performed by accounting and finance professionals will certainly be automated or significantly altered using new technologies, other activities will become more important (Bowles, 2018). Supporting earlier research by the Association of International Certified Professional Accountants (Farrar, 2018), it was found that accounting and related disciplinary roles were transforming. Perpetuating a narrow focus on accountants as a processor of 'accounting' information or documents had a limited short-term benefit. The focus instead needed to shift to the role and activities of the accountant as a business partner. The more physical and repetitive the activity, the easier it was to automate or remove the human element through robotic process automation.

The quadrant model below was developed to assess where certain activities and tasks could be clustered, and the effect of automation was predicted (Bowles, 2018, p. 34). More physical, hands- 
on activities were likely to be automated (the processor quadrant or, to a less immediate extent, the steward quadrant). Nevertheless, areas of growing demand seemed to involve human capabilities, such as offering conformance advice that drew on experience and was situated in exchanges with a client (advisor quadrant) or informed decision making associated with innovation and strategic agility (transformer quadrant). This shapes not only capability development but also career planning and skill strategies that emphasise technical accounting skills and knowledge at the expense of the human skills centred on the heart and mind (Deloitte, 2019).

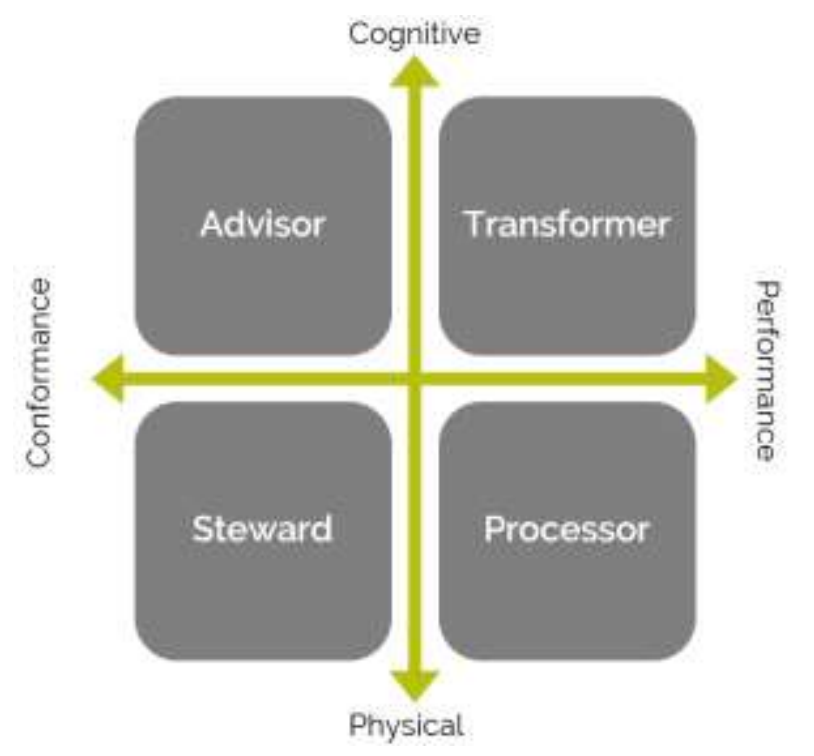

Figure 2: Reconceptualising Accounting Roles and Activities (Bowles, 2018, p. 34)

Researchers have suggested that personal, human relationships and trust built between the technically competent, professional accountant and the small business clients in Australia stimulated the decade-long growth in demand for accounting services after the global financial crisis (National Australia Bank [NAB], 2018, p. 4; The Benchmark Group, 2019). Human skills have been confirmed as forming over $70 \%$ of the skills listed on job profiles (Deloitte Access Economics, 2017), and these allow professionals to attract a wage premium of up to $10 \%$ more than their peers (Deloitte Access Economics, 2019, p. iii).

The importance of non-technical skills that some call 'soft skills', and CA ANZ have titled 'professional skills', must complement the development of technically competent graduates. The aim is to ensure graduates entering a professional career as a chartered accountant are employable.

The tendency in the past has been for many university and professional post-graduate courses to emphasise technical knowledge and theory over other non-technical and personal attributes and intelligences. Graduate attributes are also a regulatory requirement of higher education providers in Australia, who must define the qualities the graduates of their courses will hold. The research confirms that current efforts to reform curriculum must continue to ensure graduate attributes or graduate learning outcomes set the skills, knowledge, and attributes that extend beyond disciplinespecific curricula and are continuously developed within every program of study.

The CACM defines levels of proficiency that follow three levels of career and membership progress (Figure 3). It includes criteria at each of three levels-early career, leader, and executive-that offer indicators of proficiency. These can guide curriculum design, assessment, evidence gathering, and other membership services. 


\section{Description}

Acts with integrity and consistently models and promotes ethical practices in conformance with IFAC Code of Ethics, professional standards behaviour and relevant compliance requirements.

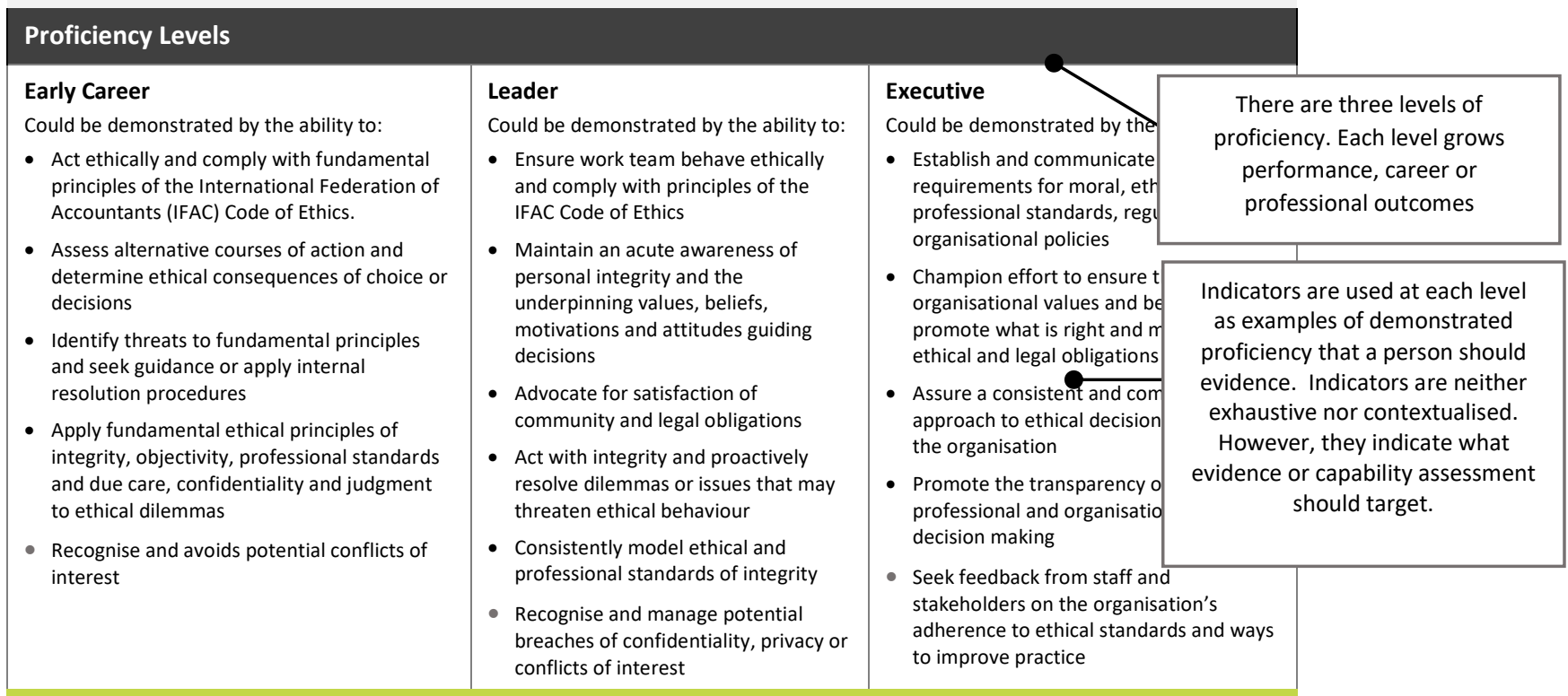

\section{Figure 3: Capability Structure and Levels}

By defining and isolating professional capabilities, CA ANZ is offering better support and significant guidance into how post-graduate accountancy and related courses should be designed to better reflect both the technical and human capabilities that chartered accountants and employers will need in the future. Moreover, the progression is linked to the CA Program and continuing professional development (CPD) that will reinforce the lifelong journey a CA ANZ members will undertake.

The development of a set of technical and non-technical capabilities for the profession will enhance the alignment of all stakeholders regarding the expectations of what graduate and chartered accountants can do at different stages of their careers. This is particularly important for new graduates. Stakeholders often have very inconsistent expectations regarding what graduates can do and their level of employability (Oliver, Whelan, Hunt, \& Hammer, 2011). The CACM is the framework that defines employability by setting the skills, knowledge, and personal attributes at different stages of career progress. Progress that can span from new graduate with less than three to five years of experience, then to the intermediate leader level, and the executive with over 10 years of experience. The stages of career development broadly align to Australian Qualifications Framework levels, 7, 8 and 9 respectively. These form standards an accounting professional will need strive to achieve when contributing to their work, community, or the economy (Yorke, 2006, p. 21).

\section{Data collection and methodology}

Much of the higher education research into graduate attributes in accounting tends to focus on the internal educational process. Views on which capabilities or skills are required by graduates therefore come from the input side of the education-employment process, including from students (Jackling \& De Lange, 2009; Oliver et al., 2011; Smith et al., 2018; McGuigan \& Kern, 2010; Wells et al., 2009), and educators (Hancock et al., 2009; Tempone et al., 2011; Zaharim et al., 2010). However, CA ANZ, as the professional body in Australia and New Zealand, sought to ensure its focus 
was on how the standards being set reflect what is required by both their major employer stakeholders and the accounting profession. The by-product of identifying what accountants require in order to be technically competent and responsive to changes in the future labour market was an evidence-based set of standards that tertiary education providers can reference to ensure their graduates acquire skills that are employable in the future.

Despite arguments suggesting employers believe it is the responsibility of universities to develop the enduring skills post-graduate accounting degree students will require to be employable, evidence suggests that all stakeholders respond more positively when the professional body provides informed guidance (Maxwell, Scott, Macfarlane, \& Williamson, 2010; Tempone et al., 2011; Nagarajan \& Edwards, 2015). This guidance is even more effective when linked to international professional competency or curriculum frameworks that ensure students gain portable skills and that companies can access global talent (Edmondson et al., 2012). The focus of the validation research was, therefore, to confirm the priority capabilities that accounting professions at all levels of employment from early career graduates to senior executives across Australia and New Zealand viewed as most important.

\section{Research questions}

\section{CA ANZ sought to confirm:}

1. Which non-technical capabilities are most relevant to the current work and are important to develop for future work roles?

2. Which capabilities are perceived to be the highest priority for CA ANZ members to hold or develop?

3. Which capabilities should CA ANZ focus on to build a sustainable future for the accounting profession?

\section{Method}

A modified occupational analysis process was used to establish and classify the capabilities for the future accounting profession. Following the established methodologies for professional jobs (Cunningham, 1988; Fleishman, 1967; McCormick, 1979; Brannick \& Levine, 2002), the following actions were required:

1. Set the parameters: Classify the professionals (occupations and roles) being studied;

2. Define the tasks and activities required in the roles;

3. Define the outputs: Define the capabilities describing the professional tasks and aggregated domains of related activities or functions at a level of proficiency;

4. Validate the capabilities through the following:

a. Review by a subject matter expert (SME) to check or rate each capability according to its application or relevance to the professional requirements in the workforce;

b. Survey a wide array of job incumbents or knowledgeable SMEs who can rate the importance or relevance of each capability across a comprehensive range of employment contexts and required locations.

The first three steps had been completed prior to this validation research project. The SMEs were sourced from a list of 3,000 self-nominated and invited CA ANZ members and stakeholders formed to provide a balanced sample across all regions, levels of work and specialisms within the accounting field.

The current jobs classified as existing under the profession held to the Australian and New Zealand Standard Classification of Occupations [ANZSCO] descriptions (ABS, 2013). The existing representative common accounting position profiles (CA ANZ, 2019b), ANZSCO task descriptors (ABS, 
2013), and O*NET (National Center for O*NET Development [NCOD], 2019) were used to define task or job activity inventories pertinent to accounting professions.

Unlike traditional occupational or job analysis approaches, the focus was not on validating tasks and competencies for a job (a skill set or cluster of tasks), but on validating the capabilities and then ensuring the capabilities could be aggregated into a cluster or stack for any job or occupational area within the accounting and related professions. Unlike traditional computer processing of such data (i.e., Common Online Data Analysis Platform [CODAP]), an analysis was undertaken not to present a set of competencies tied to a 'job' or a level of work (an ANZSCO classification or sub-classification) that was later validated by SMEs. Rather, a comparative analysis was undertaken on the capabilities themselves using the latent Dirichlet allocation to compare the capabilities to other professional frameworks deployed by GAA members. The aim was to ensure that the organising scheme for classifying and describing accounting technical and non-technical capabilities provided a robust and consistent perspective without overlaps or major gaps in terms of coverage of common accounting activities (Bowles, Bowes, \& Wilson, 2019).

Consistent with occupational analysis processes, the validated capabilities could still be sorted and used to form role descriptions, career ladders, performance and development frameworks, job design, learning and development solutions, workforce plans, and succession plans (Boyce \& Gould, 1999). Moreover, as jobs change, the clusters of capability can be resorted to consistently ensure that professionals are recruited or developed for the new roles. Focusing on the capabilities required for tasks and activities across the professional workforce, rather than for a job, provides a more flexible, reliable, and effective way to undertake workforce planning and cope with changing modes of work.

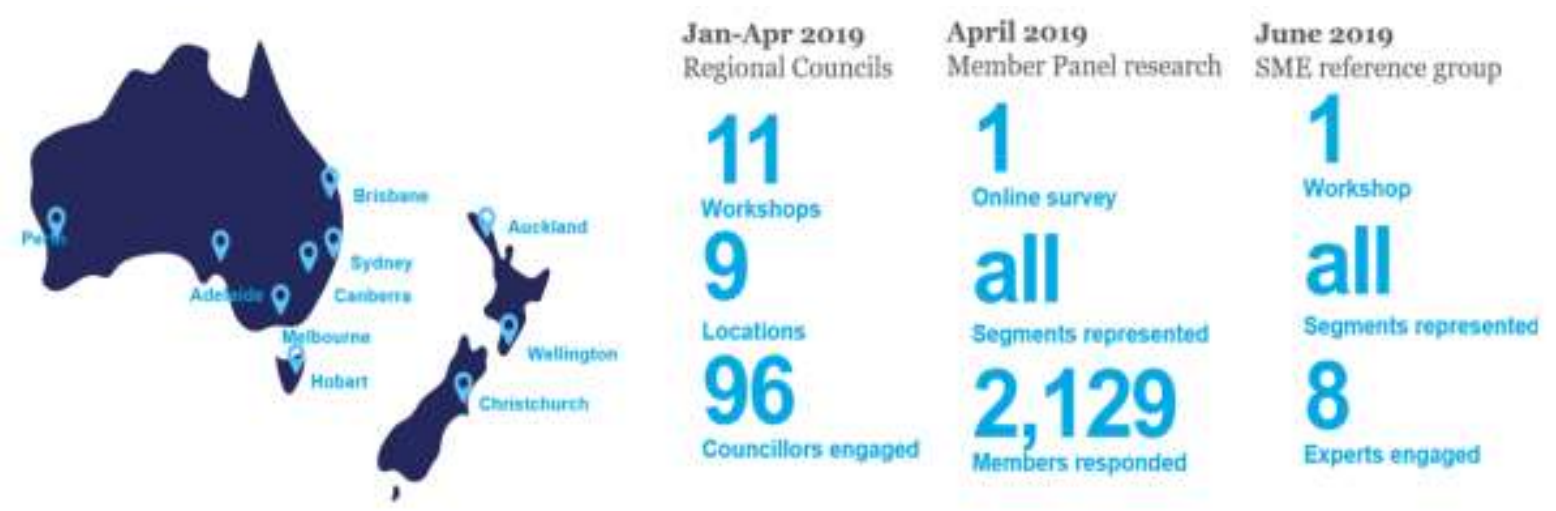

Figure 4: CA ANZ Consultation and Validation of the Draft CACM

In Step 4, validation (the focus of this paper) occurred through the following two investigations:

1. Consultation and request for input from regional councils and stakeholder SMEs; and

2. Using a modified occupational analysis approach, the draft CACM descriptors were constructed into an inventory and a survey conducted with a sample (2,129 respondents) of CA ANZ SMEs, stakeholders, and members who had self-nominated to provide independent input into any major research project involving all regions and areas of practice.

\section{Findings}

\section{Respondents}

The target audience for this research project was CA ANZ members. Out of the 3,000 survey invitations sent out to members willing to be involved in the research via CA ANZ's Member Insights Panel, 2,129 valid responses were received from accountants currently employed in organisations (corporate, practice, government, not-for-profit, and education). Moreover, 65\% of respondents 
belonged to Australia, and the remaining $35 \%$ were from New Zealand. In addition, $57 \%$ of the respondents were male, and $42 \%$ were female. The remaining $1 \%$ opted to not declare their gender. Whereas $80 \%$ of the respondents were working in an accounting or finance role, the remaining $20 \%$ of the respondents were working in another type of role (not specified) and belonged to various industries, such as manufacturing, financial and insurance services, education and training, and many others. Furthermore, $19 \%$ of the respondents identified themselves as early career employees, $42 \%$ as leaders who managed teams, functions, divisions, or business units, and the remaining $40 \%$ as experienced leaders responsible for the governance of an organisation. The majority (15\%) of the respondents belonged to the age range between 50 and 54 years old and the other respondents identified themselves as being between the ages of 45 and $49(14 \%), 35$ and $39(14 \%), 40$ and 44 $(13 \%), 30$ and $34(12 \%), 55$ and $59(12 \%), 25$ and $29(9 \%), 60$ and $64(6 \%), 65$ and $69(3 \%), 18$ and 24 (2\%), and 70 and $74(1 \%)$.

\section{Results}

The aim of this research was to validate the capabilities that are considered important to accountants in the current roles and those that will emerge in the future. The results in this section have been organised by the following:

- Importance of capabilities for each domain (personal, business, and leadership);

- Importance of capability for each domain in each country (Australia and New Zealand); and

- Overall importance of capabilities (by removing domains and countries).

The importance of each capability is presented with descending ranking (mean score: high to low; minimum 0 and maximum 10 ) with importance to current and future roles of accountants.

\section{Importance of capabilities by domain}

\section{Domain: Personal}

In this domain, the respondents ranked the capabilities in a similar order of importance for both current and future roles as accountants (summarised in Table 1). The capability of 'ethics and integrity' was ranked as the most important, closely followed by the capabilities of 'critical thinking and judgement', 'adaptive mindset', and 'self-management and learning'. The low values of the standard deviation (ranging from 1.11 to 1.73 for current and 1.06 to 1.56 for future) and variance (ranging from 1.55 to 2.05 for current and 1.52 to 2.14 for future) indicated consistency in the perception of the importance of the capabilities. The capability of 'global citizenship' was ranked the lowest in terms of importance. However, the comparatively higher standard deviation (2.28 for current and 2.22 for future) and variance (5.19 for current and 4.92 for future) in data towards ranking the capability of 'global citizenship' indicated that the perception towards its importance may have varied due to the variables (e.g., age, gender, and organisation type). For example, the capability of 'global citizenship' may have been considered very important by respondents working in a non-profit organisation but less important by respondents working in a corporate organisation.

\section{Table 1: Ranking of Capabilities by Domain (Personal)}

\begin{tabular}{|l|l|l|}
\hline $\begin{array}{l}\text { Ranking of capability's } \\
\text { importance }\end{array}$ & Important to current role & Importance to future role \\
\hline 1 (Highest) & Ethics and integrity & Ethics and integrity \\
\hline 2 & Critical thinking and judgement & Critical thinking and judgement \\
\hline 3 & Adaptive mindset & Adaptive mindset \\
\hline 4 & Self-management and learning & Self-management and learning \\
\hline 5 (Lowest) & Global citizenship & Global citizenship \\
\hline
\end{tabular}

Bowles, M., Ghosh, S., \& Thomas, L. (2020). Future-proofing accounting professionals: Ensuring graduate employability and future readiness. Journal of Teaching and Learning for Graduate Employability, 11(1), 1-21. 
The capabilities ranked similarly for both current and future roles when isolated and analysed based on the seniority (early career, leader, and executive) of the respondents in the organisation.

\section{Domain: Business}

In this domain, the capability of 'communication' was ranked the most important for both current and future roles followed by the capabilities of 'problem solving and decision making', 'collaboration and relationships', 'customer focus', and 'digital acumen' for current roles (for the future role, the ranking was similar except 'collaboration and relationships' was ranked higher than 'problem solving and decision making'). The ranking of the capabilities for this domain is summarised in Table 2 . The low values of standard deviation (ranging from 1.11 to 1.73 for current and 1.06 to 1.56 for future) and variance (ranging from 1.55 to 2.05 for current and 1.52 to 2.14 for future) indicated the consistency in the perception of the importance of the capabilities. The capability of 'business and data analysis' ranked the lowest in terms of importance for both current and future roles. However, the comparatively higher standard deviation (1.94 for current and 1.76 for future) and variance (3.76 for current and 3.10 for future) in data towards ranking the capability of 'business and data analysis' indicated that the perception towards its importance may have varied due to variables (e.g., age, gender, and type of organisation). For example, 'business and data analysis' is a specific capability that may have been appealing to respondents working in leadership and executive roles and not to the respondents in the early stages of their career.

\section{Table 2: Ranking of Capabilities by Domain (Business)}

\begin{tabular}{|l|l|l|}
\hline $\begin{array}{l}\text { Ranking of capability's } \\
\text { importance }\end{array}$ & Important to current role & Importance to future role \\
\hline 1 (Highest) & Communication & Communication \\
\hline 2 & $\begin{array}{l}\text { Problem-solving and decision } \\
\text { making }\end{array}$ & $\begin{array}{l}\text { Collaboration and } \\
\text { relationships }\end{array}$ \\
\hline 3 & $\begin{array}{l}\text { Collaboration and } \\
\text { relationships }\end{array}$ & $\begin{array}{l}\text { Problem-solving and decision } \\
\text { making }\end{array}$ \\
\hline 4 & Customer focus & Customer focus \\
\hline 5 & Digital acumen & Digital acumen \\
\hline 6 (Lowest) & Business and data analysis & Business and data analysis \\
\hline
\end{tabular}

The capabilities ranked similarly for both current and future roles when isolated and analysed based on the seniority of the respondents in the organisation.

\section{Domain: Leadership}

In this domain, the respondents ranked the capability of 'agility and change' as the most important followed by 'drive for results', 'future focus', 'risk and governance', and 'leading and developing others' for the current roles. In comparison to the current roles, the capabilities ranked most important for future roles were 'future focus' followed by 'agility and change', 'drive for results', 'leading and developing others', and 'risk and governance'. The inconsistency in ranking for current and future roles may be attributed to the relative similarity in the values of standard deviation and variance for all the ranked capabilities (i.e., the respondents perceived the importance of the listed capabilities for leadership roles differently based on their age, gender, type of organisation they worked in, and other variables). However, the capability of 'innovation and creativity' ranked the lowest for both current and future roles. 
Table 3: Ranking of Capabilities by Domain (Leadership).

\begin{tabular}{|l|l|l|}
\hline $\begin{array}{l}\text { Ranking of capability's } \\
\text { importance }\end{array}$ & Important to current role & Importance to future role \\
\hline 1 (Highest) & Agility and change & Future focus \\
\hline 2 & Drive for results & Agility and change \\
\hline 3 & Future focus & Drive for results \\
\hline 4 & Risk and governance & Leading and developing others \\
\hline 5 & Leading and developing others & Risk and governance \\
\hline 6 (Lowest) & Innovation and creativity & Innovation and creativity \\
\hline
\end{tabular}

The capabilities ranked similarly for both current and future roles when isolated and analysed based on the seniority of the respondents in the organisation. Nevertheless, stage of career did influence the overall ranking for some of the capabilities considered least important. As depicted below, the importance of capabilities in current role were considered significantly less important for many new graduates.

\begin{tabular}{ll|c|c|c|c|c|c|} 
& & \multicolumn{3}{|c|}{ Importance current role } & \multicolumn{3}{c|}{ Importance future roles/ career } \\
Domain & Capabilities & Early career & Leader & Executive & Early career & Leader & Executive \\
\hline Business & Business and data analysis & 7.62 & 7.88 & 7.81 & 8.57 & 8.58 & 8.19 \\
& Digital acumen & 8.09 & 8.01 & 7.84 & 8.76 & 8.71 & 8.35 \\
\hline \multirow{2}{*}{ Leadership } & Innovation \& creativity & 6.85 & 7.62 & 8.01 & 8.19 & 8.47 & 8.40 \\
& Risk a Governance & 7.01 & 7.94 & 8.50 & 8.10 & 8.46 & 8.57 \\
\hline Personal & Global citizenship & 6.77 & 7.19 & 7.27 & 7.77 & 7.92 & 7.64 \\
\hline
\end{tabular}

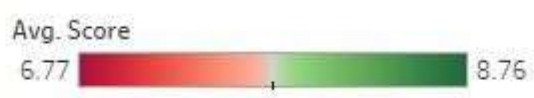

Figure 5: Capability Rating by Career Stage (current vs. future roles)

Importance of capabilities by each domain in each country

Country: Australia (Domain: Personal, Business, and Leadership)

The ranking of capabilities by the Australian respondents in the domains matched the ranking of the capabilities when isolated for the respective domain (as discussed above). Hence, the capabilities (global citizenship, business and data analysis, and innovation and creativity) that ranked lowest in the individual domain did the same for the Australian respondents. Considering that most respondents (65\%) were Australian, this finding was anticipated. However, the data analysis revealed a thought-provoking fact about the capability of 'ethics and integrity'. Although all the capabilities received a higher mean score for future roles as compared to current roles, it was only the capability of 'ethics and integrity' that received a marginally higher mean score for current roles when compared to future roles. This finding indicated that the Australian respondents considered the capability an important part of their professional behaviour throughout their careers.

Table 4: Ranking of Capabilities by each Domain in Australia

\begin{tabular}{|l|l|l|l|}
\hline $\begin{array}{l}\text { Ranking of } \\
\text { capabilities }\end{array}$ & Domain & $\begin{array}{l}\text { Important to current } \\
\text { role }\end{array}$ & $\begin{array}{l}\text { Importance to future } \\
\text { role }\end{array}$ \\
\hline Most important & Personal & Ethics and integrity & Ethics and integrity \\
\hline Least important & Personal & Global citizenship & Global citizenship \\
\hline
\end{tabular}

Bowles, M., Ghosh, S., \& Thomas, L. (2020). Future-proofing accounting professionals: Ensuring graduate employability and future readiness. Journal of Teaching and Learning for Graduate Employability, 11(1), 1-21. 


\begin{tabular}{|l|l|l|l|}
\hline Most important & Business & Communication & Communication \\
\hline Least important & Business & $\begin{array}{l}\text { Business and data } \\
\text { analysis }\end{array}$ & $\begin{array}{l}\text { Business and data } \\
\text { analysis }\end{array}$ \\
\hline Most important & Leadership & Agility and change & Future focus \\
\hline Least important & Leadership & $\begin{array}{l}\text { Innovation and } \\
\text { creativity }\end{array}$ & $\begin{array}{l}\text { Innovation and } \\
\text { creativity }\end{array}$ \\
\hline
\end{tabular}

Country: New Zealand (Domain: Personal, Business, and Leadership)

The ranking of capabilities by the New Zealander respondents in the domains matched the ranking when the responses were isolated for the respective domain and those provided by their Australian counterparts (as discussed above). For the domain of 'leadership', however, the only difference from previous rankings was that the capability of 'risk and governance' (and not 'innovation and creativity') was ranked the lowest for future roles. Similar to their Australian counterparts, the New Zealander respondents also provided a higher mean score for all the capabilities for future roles except for the capability of 'ethics and integrity', which received a marginally higher score for current roles compared to the future roles. Hence, it may be implied that ethical behaviour and conduct are considered essential for the profession throughout the careers of the accountants in New Zealand.

Table 5: Ranking of Capabilities by each Domain in New Zealand

\begin{tabular}{|l|l|l|l|}
\hline $\begin{array}{l}\text { Ranking of } \\
\text { capabilities }\end{array}$ & Domain & $\begin{array}{l}\text { Important to current } \\
\text { role }\end{array}$ & $\begin{array}{l}\text { Importance to future } \\
\text { role }\end{array}$ \\
\hline Most important & Personal & Ethics and integrity & Ethics and integrity \\
\hline Least important & Personal & Global citizenship & Global citizenship \\
\hline Most important & Business & Communication & Communication \\
\hline Least important & Business & $\begin{array}{l}\text { Business and data } \\
\text { analysis }\end{array}$ & $\begin{array}{l}\text { Business and data } \\
\text { analysis }\end{array}$ \\
\hline Most important & Leadership & Agility and change & Future focus \\
\hline Least important & Leadership & $\begin{array}{l}\text { Innovation and } \\
\text { creativity }\end{array}$ & Risk and governance \\
\hline
\end{tabular}

\section{Overall importance of capabilities (removing domains and countries)}

The ranking of the capabilities and their overall importance to the current and future roles was also studied by removing the domains and countries of the respondents (summarised in Figure 5). The results revealed that the capabilities of 'ethics and integrity' and 'communication' ranked the most important for current and future roles, respectively. The capability of 'global citizenship' ranked the lowest for both current and future roles. It was also noted that the top seven capabilities ranked for both current and future roles belonged to the domains of 'personal' and 'business', which indicated that the respondents perceived the 'leadership' capabilities secondary to the other two domains for their professional roles as accountants.

Statistically, the overall results suggest that a general belief remains that capabilities considered important today are still considered important in the future. At this stage, the research does not suggest that any capability or set of capabilities has a short shelf life. The results of the survey were in no way consistent with the expectations or earlier SME feedback. 
This research clarifies which capabilities are considered most important today and into the future. It confirms that all professional accountants, irrespective of role, level of employment, experience, location, or stage of career considered the following six capabilities of the highest importance to current and future work:

1. Communication (business domain)

2. Ethics and integrity (personal domain)

3. Problem solving and decision making (business domain)

4. Critical thinking and judgement (personal domain)

5. Adaptive mindset (personal domain)

6. Collaboration and relationships (business domain)

The most profound of the results were the six capabilities rated as the lowest of all 17 capabilities in terms of current and future importance for current or future accounting work (from the lowest rating):

- Digital acumen (business domain)

- Business and data analysis (business domain)

- Risk and governance (leadership domain)

- Innovation and creativity (leadership domain)

- Global citizenship (personal domain)

- Leading and developing others (leadership domain)

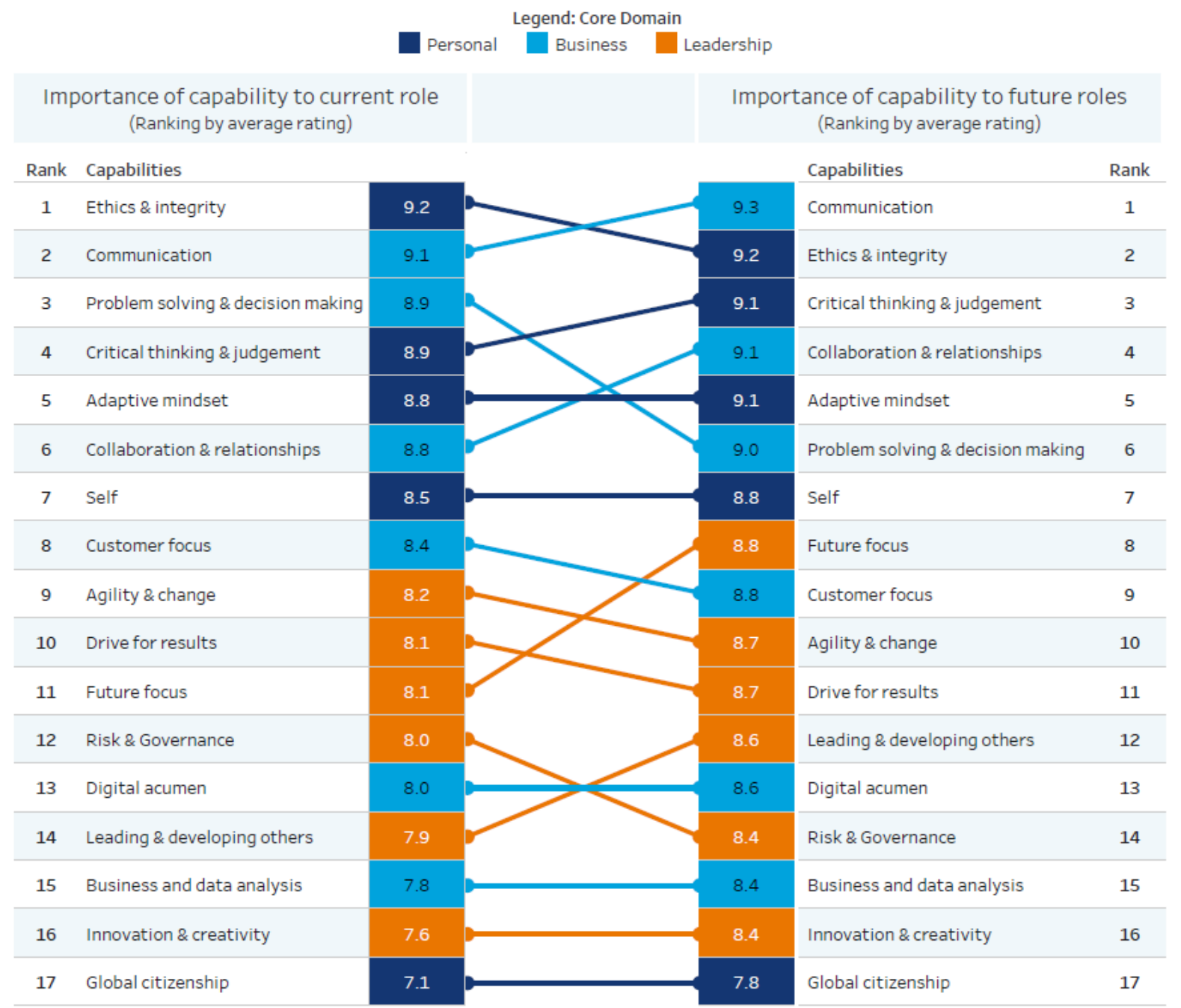

Figure 6: Capability Rankings - Summary Results 
It should be clear that the ranking of the bottom capabilities does not make them redundant or irrelevant for current or future roles. The capabilities were ranked mainly based on their mean score, but the difference in scores between the capabilities should not be considered very significant. However, the bottom six capabilities did indicate a high variance and standard deviation, which further indicated an inconsistency among respondents on the capabilities they considered least important. The high variance scores indicate that many respondents may have considered the bottom-ranked capabilities to be as important as the top-ranked capabilities (and hence the relative difference in mean score is not significantly different), but the percentage of the respondents who perceived their lower importance was higher than other capabilities. For example, it may be implied that the high percentage of the respondents belonging to leadership and executive roles (81\%) may have dictated the ranking of the top six capabilities, and although the early career respondents considered the bottom six capabilities to be equally important, due to their low percentage $(19 \%)$, the capabilities could not achieve statistical significance in terms of ranking.

The above results do confound the general feedback from those consulted in the earlier rounds of validation. Equally, benchmarking with the research being conducted against GAA member frameworks suggests that the transformation of the profession into the future will rely on working with the following:

- technology-enhanced roles (digital, data and analysis);

- a global market and regulatory context (governance and risk); and

- new and creative ways to add value to a business (innovation and creativity).

The results were taken to the reviewing project committee and a final SME workshop comprising globally rated experts from Australia and New Zealand. The results and technical debate resulted in the SME final workshop suggesting revisions to the actual capability model (CA ANZ, 2019a).

Global citizenship was oriented away from a globalised business context to more tightly address its inclusion under the personal domain and was retitled regard for others.

With the inclusion of creativity in innovation and creativity, experts believed it was ambiguous as a professional accounting capability. It was restructured to focus on how innovation was conducted (action) as part of the leadership domain. Editing also ensured creativity was covered in the existing adaptive mindset capability. Creativity, with the emphasis on how people think, was removed from the criteria, and the title was adjusted to innovation.

The digital acumen capability had only small edits. It was noted that consideration and future research were required to further determine whether new graduates saw calls by leaders and executives for greater digital and technology skills as not applying to them because they may feel they already had acquired such skills.

Risk and governance was reframed to governance and risk. Small edits were made, but the importance of the capability was confirmed. The primary emphasis should have been on governance, not risk.

Business and data analysis was felt to be too broad and lacked the desired emphasis on the future role of an accountant. The capability was also considered less relevant to the public sector and non-profit organisations. It was recast to move the capability from how a business consumes data, to emphasise how data can be used by accountants (or others in associated accounting roles) to add value to decision making.

\section{The way forward}

The CA ANZ is now focused on using the CACM to drive value for members by assisting individuals and organisations to develop the capabilities needed for the future workforce (Figure 6). The CACM provides a strategic framework that CA ANZ can use as an organising principle for all of CA ANZ products and services. As the implementation of the CACM progresses, this will include alignment of Bowles, M., Ghosh, S., \& Thomas, L. (2020). Future-proofing accounting professionals: Ensuring graduate employability and future readiness. Journal of Teaching and Learning for Graduate Employability, 11(1), 1-21. 
CPD solutions and education offerings, thought leadership activities and research focus areas, and public programs and events offered by CA ANZ. Several such implementation initiatives in planning will assist in delivering on this value objective by bringing the CACM to life in various ways.

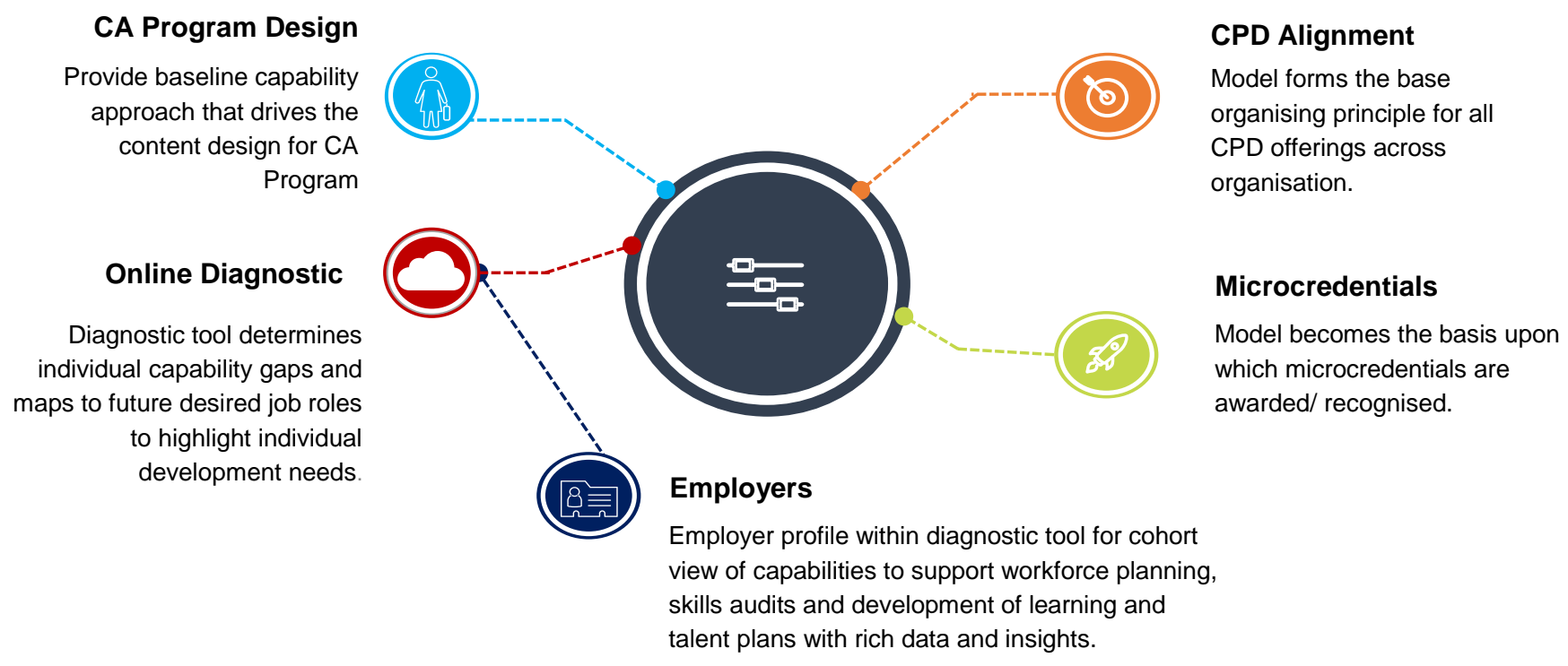

\section{Figure 7: From Capability Framework to Professional Services}

The first of the CACM applications for CA ANZ is the direct alignment of the core capabilities to the graduate attributes that have been confirmed in a refresh of the design of CA ANZ's core CA Program. The six professional capabilities isolated in the research ('communication', 'collaboration and relationships', 'problem solving and decision making', 'ethics and integrity', 'critical thinking and judgement', and 'adaptive mindset') have shaped the core graduate attributes and skills, knowledge, and personal attributes that graduates of the revised post-graduate CA Program will hold (as shown in Figure 8).

Another key initiative in planning by CA ANZ is the provision of a self-assessment tool to support continued relevance and career success for members and enhanced capacity for strategic workforce development for organisations. The CACM will be used as the foundation for an integrated online diagnostic solution that combines competency assessment with personalised guidance around professional development opportunities aimed at both individuals and organisations. The solution will allow individuals and organisations to assess their capability against the model and compare this to the capability requirements of key common industry roles. Based on the individual capability assessment, the tool will diagnose key areas for development and provide personalised recommendations for relevant CPD activities that can be accessed directly through the platform to assist the development of those key capability areas.

To further support organisations with capability insights to guide strategic workforce development efforts, the solution will provide organisational leaders with a team view of capability across a cohort of individuals enabling common capability gaps to be identified, and cohort-relevant, targeted CPD activities to be suggested. The personalisation of the capability gap analysis will enable CA ANZ to grow its portfolio of offerings, incorporating learning solutions that are increasingly flexible in delivery and that target capabilities and career level needs in "high demand". Finally, the CACM provides the ideal framework to enable the awarding of micro-credentials across a range of CPD offerings and other areas within the service offerings for members. 


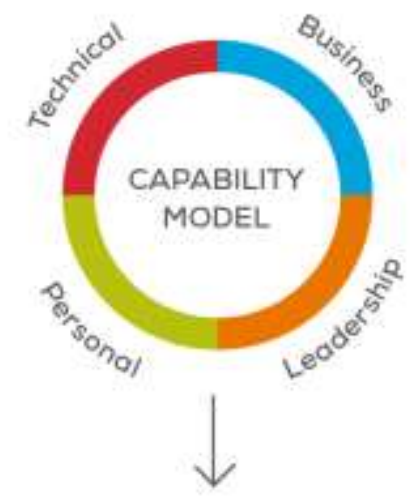

CAPABILITY FRAMEWORK

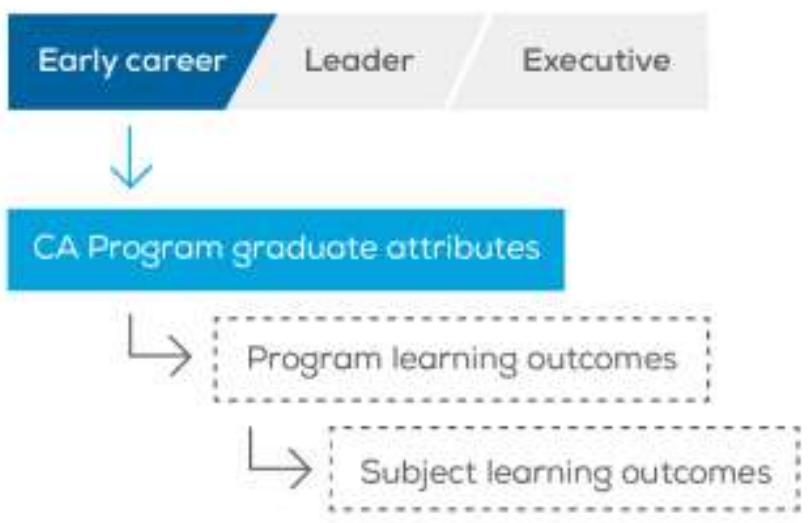

Figure 8: From Capability to Graduate Attributes and Learning Outcomes that Improve Employability

\section{References}

$2^{\text {nd }}$ Road (October 2017). Discovery: Design research on member experience. Strategy Development 2017. Sydney, Chartered Accountants Australia and New Zealand.

Accounting Professional Ethics and Standards Board [APESB] (2018). APESB 110 Code of Ethics for Professional Accountants. APESB Limited, Melbourne. Retrieved October 2019 at https://www.apesb.org.au/uploads/home/02112018000152 APES 110 Restructured_Code Nov 2018 .pdf.

Albrecht, W., \& Sack, R. (2000). Accounting education: Charting the course through a perilous future. American Accounting Association, Sarasota, Florida.

AlphaBeta (2019). Future Skills. Google Australia, Sydney. Retrieved May 2019 at https://www.alphabeta.com/wp-content/uploads/2019/01/google-skills-report.pdf.

Australian Bureau of Statistics [ABS] (June 2013). 1220.0 - ANZSCO -- Australian and New Zealand Standard Classification of Occupations, Version 1.2. ABS, Canberra. Available online at https://www.abs.gov.au/ANZSCO. Retrieved June 2019 at https://www.abs.gov.au/ANZSCO.

Association of Chartered Certified Accountants [ACCA] (2016). Professional accountants: Drivers of change and future skills. ACCA, London. Retrieved May 2019 at https://www.accaglobal.com/content/dam/members-beta/images/campaigns/pa-tf/pi-professionalaccountants-the-future.pdf

Australian Bureau of Statistics [ABS] (June 2013). 1220.0 - ANZSCO -- Australian and New Zealand Standard Classification of Occupations, 2013, Version 1.2. Commonwealth of Australia, Canberra.

Australian Business Deans Council [ABDC] (2016). Accounting Learning Standards. Retrieved 8 October 2019 at https://abdc.edu.au/data/Accounting LS/New TLS Final 2016.pdf.

Benbow, R.J., \& Hora, M.T. (2018). Reconsidering college student employability: A cultural analysis of educator and employer conditions of workplace skills. Harvard Educational Review, 88(4), 483-515. 
Bersin, J., Stempel, J., \& van der Vyver, B. (7 March 2014). The quest for workforce capability: Create a global skills supply chain. Deloitte Insights. Deloitte University Press. Retrieved 3 October 2019 at https://www2.deloitte.com/us/en/insights/focus/human-capital-trends/2014/hc-trends-2014workforce-capability.html.

Big Eight managing partners (1989). Perspectives on education: Capabilities for success in the accounting profession. White Paper, Arthur Andersen, Arthur Young \& Co, Coopers \& Lybrand, Deloitte, Haskins \& Sells, Ernst \& Whinney, Peat Marwick Main \& Co, and Price Waterhouse and Touche Ross, New York.

Bowles, M., \& Schoenheimer, H. (2009). Developing human capability. Sydney, Andermark.

Bowles, M. (2018). Future Accountant, White Paper. Sydney, Chartered Accountants Australia and New Zealand.

Bowles, M. (January 2019). Future Capabilities Reference Framework: Update to the LaMDA ${ }^{\text {TM }}$ Leadership and Management Capability Framework Guide. Melbourne, Working Futures. DOI: 10.13140/RG.2.2.12165.60645.

Bowles, M., Bowes, N., \& Wilson, P. (2019). Future-proof human capabilities: Raising the future employability of graduates. International Journal of Business and Social Science, 10(11), 18-29.

Boyce, L.A., \& Gould, R.B. (1999). Tasks difficulty measurement by the United States Air Force Occupational Measurement. Brooks, USA, USAF Research Laboratory.

Brannick, M.T., \& Levine, E.L. (2002). Job analysis: Methods, research and applications for human resource management in the New Millennium. Thousand Oaks, California, Sage.

Chartered Accountants Australia and New Zealand [CA ANZ] (September, 2017a). CA Success profiles. Sydney \& Wellington, CA ANZ. Available online at https://www.charteredaccountantsanz.com/learning-andevents/learning/ca-success-profiles.

CA ANZ (2017b). The future of talent: Opportunities unlimited, future [inc] ${ }^{\mathrm{TM}}$. Sydney, CA ANZ \& PwC.

CA ANZ (15 May 2019a). CA capability model: Summary of validation SME workshop findings. Sydney, CA ANZ.

CA ANZ (July 2019b). Common accounting profession role profiles with employment growth and remuneration indicators, Version 2. Sydney, CA ANZ.

CA ANZ (August 2019c). Program design specification CA X. Sydney, CA ANZ.

Chartered Professional Accountant (Canada) [CPAC] (2019). The Chartered Professional Accountant Competency Map: Understanding the competencies a candidate must demonstrate to become a CPA. Canada, Toronto, CPA.

Crisp, G., \& Oliver, B. (2019). Re-imagining graduate achievement and employability. In J. Higgs et al. (Eds.), Education for employability: Learning for future possibilities (Volume 1). Brill Sense, pp. 73-82. Retrieved May 2019 at https://brill.com/view/book/edcoll/9789004400832/BP000015.xml.

Cunningham, J.W. (1988). Occupation analysis inventory, In S. Gael (Ed), The job analysis handbook for business, industry, and government, Volume 2, (pp. 975-90). New York, Wiley.

DeakinCo. (2017). Professional Practice Credential Assessment Framework. Melbourne, Deakin University.

Deloitte (2016). Blockchain technology: A game-changer for accounting? Germany, Deloitte Deutschland. Retrieved 3 October 2019 https://www2.deloitte.com/content/dam/Deloitte/de/Documents/Innovation/Blockchain_A\%20gamechanger\%20in\%20accounting.pdf.

Deloitte (2019). The path to prosperity: Why the future of work is human, Building the Lucky Country \#7. Sydney, Deloitte Insights. Retrieved 6 June 2019 at https://www2.deloitte.com/au/en/pages/buildinglucky-country/articles/path-prosperity-future-work.html

Deloitte Access Economics (2017). Soft skills for business success. Melbourne, Deloitte and DeakinCo. Retrieved 13 March 2019 at https://www2.deloitte.com/au/en/pages/economics/articles/soft-skills-businesssuccess.html.

Deloitte Access Economics (2019). Premium skills: The wage premium associated with human skills. Melbourne, Deloitte and DeakinCo. Retrieved 10 December 2019 at https://www2.deloitte.com/content/dam/Deloitte/au/Documents/Economics/deloitte-au-economicspremium-skills-deakinco-060120.pdf.

Department of Education \& Training [DET] (2015). Core Skills for Work Developmental Framework. Canberra Australia, Department of Education, Employment and Workplace. Retrieved 18 March 2019 at https://docs.education.gov.au/node/37103

Edmondson, G., Valigra, L., Kenward, M., Hudson, R. L., \& Belfield, H. (2012). Making industry-university partnerships work: Lessons from successful collaborators. Belgium, Science Business Innovation Board. Retrieved 9 July 2019 at http://www.sciencebusiness.net/sites/default/files/archive/Assets/94fe6d155432-4cf9-a656-633248e63541.pdf. 
Farrar, M. (2018). Changing competencies and mindsets. USA, Chartered Global Management Accountant, Association of International Certified Professional Accountants.

Fleishman, E.A. (1967). Development of a behavior taxonomy for describing human tasks: A correlationalexperimental approach. Journal of Applied Psychology, 51(1), 1-10.

Frey, C. B, Osborne, M. A., \& Holmes, C. (2016). Technology at work v2.0: The future is not what it used to be. Oxford, Martin School, University of Oxford, CITI. Retrieved from http://www.oxfordmartin.ox.ac.uk/downloads/reports/Citi GPS Technology Work 2.pdf

Gekara, V., Snell, D., Molla, A., Karanasios, S. \& Thomas, A. (2019). Skilling the Australian workforce for the digital economy. Adelaide, NCVER.

Global Accounting Alliance [GAA] (5 August 2019b). Global Accounting Alliance Recognition Framework and Principles, Draft. Sydney, GAA, CA ANZ.

GAA, (May 2019a). GAA enabling competencies, Draft 2.03, GAA, Global Accounting Alliance Education Directors Meeting May 2019 papers: Scotland.

Hamel, G. (2003). Innovation as a deep capability. Leader to Leader, 27, 19-24. Retrieved September 2019 at http://leadershipwithoutboundaries.groupsite.com/uploads/files/x/ 000/012/ac7/A6 Innovation as a Deep Capability.doc.

Hancock, P., Howieson, B., Kavanagh, M., Kent, J., Tempone, I., \& Segal, N. (2009). Accounting for the future: More than numbers- $A$ collaborative investigation into the changing skill set for professional accounting graduates over the next ten years and strategies for embedding such skills into professional accounting programs, Vols.1 and 2. Strawberry Hills, NSW, Australian Learning and Teaching Council. Retrieved 4 May 2019 at https://Itr.edu.au/resources/DS7619\%20Accounting\%20for\%20the\%20future.\%20Final\%20report\%202009.\%20Volume\%202.pdf.

Hancock, P., Howieson, B., Kavanagh, M., Kent, J., Tempone, I., \& Segal, N. (2010). Accounting for the future. In E. Evans, R. Burritt \& J. Guthrie (Eds.), Accounting education at a crossroad in 2010 (pp. 54-62). Sydney, The Institute of Chartered Accountants in Australia.

Hancock, P., Freeman, M., Watty, K., Birt, J., \& Tyler, J. (2016). Accounting Learning Standards, Revised. Melbourne, Australian Business Deans Council. Retrieved 20 July 2019 at https://abdc.edu.au/data/Accounting LS/New TLS Final 2016.pdf

Jackling, B., \& De Lange, P. (2009). Do accounting graduates' skills meet the expectations of employers? A matter of convergence or divergence. Accounting Education, 18(4), 369-385.

Kavanagh, M., \& Drennan, L. (2008). What skills and attributes does an accounting graduate need? Evidence from student perceptions and employer expectations. Accounting and Finance, 48(2), 279-300.

Maxwell, G., Scott, B., Macfarlane, D., \& Williamson, E. (Jan. 2010). Employers as stakeholders in postgraduate employability skills development. International Journal of Management Education, 8(2), 1-11.

McCann, J., \& Selsky, J. W. (2012). Mastering turbulence: The essential capabilities of agile and resilient individuals, teams and organizations. San Francisco, California, Jossey-Bass.

McCormick, E.J. (1979). Job analysis: Methods and applications. New York, Amacom.

McGuigan, N., \& Kern, T. (2010). Leaping over the perceptual threshold in accounting courses: Embracing sustainable assessment and learning design. ATN 2010 Conference, Assessment: Sustainability, Diversity and Innovation. Sydney Australia. Retrieved 8 October 2019 at https://www.uts.edu.au/sites/default/files/McGUIGAN.pdf.

Moore, T., \& Morton, J. (2017). The myth of job readiness? Written communication, employability, and the 'skills gap' in higher education. Studies in Higher Education, 42(3), 591-609.

Nagarajan, S., \& Edwards, J. (2015). The role of universities, employers, graduates and professional associations in the development of professional skills of new graduates. Journal of Perspectives in Applied Academic Practice, 3(2), 26-37.

National Australia Bank [NAB] (2018). Key insights into the Australian accounting industry. Melbourne, NAB Professional Services.

National Center for O*NET Development [NCOD] (2019). O*NET Online. U.S., Department of Labor, Employment \& Training Administration. Available online at https://www.onetonline.org/.

New Zealand Institute of Economic Research [NZIER] (October 2015). Disruptive technologies risks, opportunities - Can New Zealand make the most of them? Wellington, Chartered Accountants Australia and New Zealand. Retrieved May 2019 at https://nzier.org.nz/static/media/filer public/6d/6e/6d6ecf8b-032c-4551-b0a78cd0f39e2004/disruptive technologies for caanz.pdf.

Oliver, B., Whelan, B., Hunt, L., \& Hammer, S. (2011). Accounting graduates and the capabilities that count: Perceptions of graduates, employers and Accounting academics in four Australian Universities. Journal of Teaching and Learning for Graduate Employability, 2(1), 2-27. 
Oliver, M. (2018). Accountant of the Future. Durban, South Africa, South African Institute of Chartered Accountants \& Global Accounting Alliance.

Organisation for Economic Co-operation and Development [OECD] (2015). Universal basic skills: What countries stand to gain. Paris, OECD Publishing. Available at http://dx.doi.org/10.1787/9789264234833en.

Queensland Tertiary Admissions Centre [QTAC] (2019). Human capability dictionary: Setting standards for future ready graduates. Brisbane, QTAC.

Regional Australia Institute [RAI] (September 2018). The RAl's Method for Assessing Regional Job Vulnerability to Automation, Shared Inquiry Program 2018. Canberra, RAI. Retrieved November 2018 at http://www.regionalaustralia.org.au/home/wpcontent/uploads/2018/06/180830 JobVulnerabilityMethod Final.pdf.

Scott, G., Coates, H., \& Anderson, M. (May 2008). Learning leaders in times of change: Academic leadership capabilities for Australian higher education. Sydney, University of Western Sydney and Australian Council for Educational Research.

Siegel, G., \& Sorensen, J.E. (1994). What corporate America wants in entry-level Accountants. Management Accounting Research, 15(4), 441-469. A Joint Research Project of the Institute of Management Accountants and the Financial Executives Institute, The Institute of Management Accountants.

Smith, B., Maguire, W., \& Han, H.H. (2018). Generic skills in accounting: Perspectives of Chinese postgraduate students. Accounting and Finance, 58(2), 535-559. DOI 10.1111/acfi.12219.

Teece, D. (2007). Explicating dynamic capabilities: The nature and micro foundations of (sustainable) enterprise performance. Strategic Management Journal, 28(13), 1319-1350.

Tempone, I., Kavanagh, M., Seagal, N., Hancock, P., \& Howieson, B. (2011). Embedding non-technical skills into the accounting curricula. Research Paper. Melbourne, Australian Learning and Teaching Council, Swinburne University of Technology. Retrieved May 2019 at https://researchbank.swinburne.edu.au/file/f5a62ad8-813c-4c0c-b22029bf4009c07a/1/PDF\%20\%28Published\%20version\%29.pdf

The Benchmarking Group (2019). The silent disruption of the accounting industry. Adviser Voice. Retrieved May 2019 at https://www.adviservoice.com.au/2019/06/the-silent-disruption-of-the-accountingindustry/.

Tingey-Holyoak, J., \& Burritt, R. (June 2012). The transdisciplinary nature of accounting: A pathway towards the sustainable future of the profession. In E. Evans, R. Burritt \& J. Guthrie (Eds), Emerging pathways for the next generation of accountants (Chapter 10, pp. 93-103). Adelaide, Institute of Chartered Accountants in Australia \& University of South Australia.

Towers-Clark, J. (2016). Are undergraduate accounting students developing transferable skills that meet stakeholder needs? An international study. Doctoral Thesis, UCL Institute of Education, University of London: London. Retrieved 8 September 2019 at http://discovery.ucl.ac.uk/1502408/1/TowersClark IOE\%20final\%20thesis\%20J\%20Towers-Clark.pdf.

Wells, P., Gerbic, P., Kranenburg, I., \& Bygrave, J. (September-December 2009). Professional skills and capabilities of accounting graduates: The New Zealand expectation gap? Accounting Education: An International Journal, 18(4-5), 403-420.

World Economic Forum [WEF] (September 2018). Future of Jobs Survey 2018. Switzerland, Centre for New Economy and Society. Retrieved May 2019 at http://www3.weforum.org/docs/WEF Future of Jobs 2018.pdf.

Yorke, M. (2006). Employability in higher education: What it is - What it is not. York, UK, The Higher Education Academy.

Zaharim, A., Yusoff, Y., Omar, M.Z., Mohamed, A., \& Muhamad, N. (2010). The comparison on priority engineering employability skills. International Journal of Engineering and Technology, 7(2), 61-74. 